\title{
Structural factor of reducing interterritorial inequality in the post-Covid period
}

\author{
Olga Romanova ${ }^{1 *}$, and Alena Ponomareva ${ }^{1}$ \\ ${ }^{1}$ Institute of Economics of the Ural Branch of the Russian Academy of Sciences, 620014, \\ Ekaterinburg, Russian Federation
}

\begin{abstract}
Carrying out large-scale structural transformations of both the entire Russian economy and its individual actors is one of the most important tasks of the current stage of national development. The urgency of this problem has increased dramatically during the COVID-19 pandemic. The purpose of this paper is to identify the most significant factors in the pandemic that affect the economic growth of Russia's regions and reduce territorial inequality. The use of methods of comparative and economic-statistical analysis made it possible to establish that the most important independent factor in the development of a region is the structure of the economy and such a factor that ensures it as the regional structural (industrial) policy. It has been substantiated that structural modernization is the basis for pursuing a non-contradictory short- and long-term policy to reduce interterritorial inequality. A particularly negative impact of the pandemic on regions with a low level of development of the real sector and overdevelopment of the service sector has been revealed.
\end{abstract}

Keywords: COVID-19, interterritorial inequality, structural factor, the regulating role of the state

\section{Introduction}

One of the most important tasks of the current stage of Russia's development is the formulation of a long-term policy to achieve economic growth and the implementation of large-scale structural transformations. However, a solution to these tasks is impossible without a deeper consideration of the spatial aspect of the national development, the features of the existing potential of Russia's regions, the level of socio-economic development, and the structural features of the country's regions. The vulnerability of the structure of the Russian economy as a whole, as well as of individual regions, was fully manifested in 2020-2021, that is, during the COVID-19 coronavirus infection pandemic. At the World Economic Forum in Davos, a special COVID Action Platform was created, which stated: "The dramatic spread of COVID-19 has destroyed lives, livelihoods, communities and businesses around the world" [1]. In these conditions, it becomes especially important to build a state long-term policy of economic development, taking into

\footnotetext{
${ }^{*}$ Corresponding author: romanova.oa@uiec.ru
} 
account not only the new realities, the spatial characteristics of the country but also the importance of combining the implementation of short-term changes caused by external factors, such as the novel coronavirus pandemic, with medium- and long-term trends in technological and institutional development.

\section{Factors of Development}

When forming such a balanced policy, it is important to take into account the factors influencing the economic development of Russia's regions and to single out the most significant ones in the pandemic context. The systematization of development factors is largely determined by the basic theories underlying it. One can note the works of Rodrik, where all factors of regional development are classified as proximate and deep [2, 3], while the spatial factor is highlighted as a significant one. In works on the new structural economics, Lin emphasizes the special importance of the infrastructural factor [4]. The World Bank identifies such three factors as density, distance, separation [5]. The last of them (separation) is convincingly interpreted by Zubarevich as institutional barriers [6].

However, from the standpoint of identifying the factors that contribute to the reduction of interterritorial inequality, the most interesting is the five-level model developed by Kuznetsova [7]. The first level is the objective basic factors, such as resources and natural and climatic conditions; at higher levels, there are demography and settlement, then - the infrastructure provision, followed by the level of development and structure of the economy of a territory. The pyramid is finished with subjective, institutional factors that form the "rules of play". However, among their large number, in the authors' opinion, only state and municipal socioeconomic policies are rightfully distinguished by her. It seems that the level of development and the territorial structure of the economy in today's conditions are not only the cumulative result of the impact of the above factors. The structure of a region's economy is becoming an independent factor, a kind of imperative for its economic development, and the main instrument for implementing this factor is structural (industrial) policy.

Under these conditions, pursuing a non-contradictory short- and long-term policy is possible only on the basis of structural modernization. Overcoming the consequences of the coronavirus has already determined that there is no alternative to a number of structural reforms that are important not only at the state level, but, above all, at the level of the constituent entities of the Russian Federation. The state's structural agenda focused on the problem of health care modernization, whose social, economic, and even political roles seriously affect budget priorities. The dynamics of the employment structure in the industrial regions of Russia by types of economic activity (Fig. 1) indicates the absence of sharp structural changes. At the same time, a higher portion of people employed in manufacturing in the industrialized regions can be noted in comparison with the indicator for Russia as a whole, $20.6 \%$ and $14 \%$, respectively. However, the indicators of those employed in trade, information, and communications, as well as in health care and social services, in industrialized regions are lower than those in Russia, being 19\%, 2\%, 6.2\% there. 


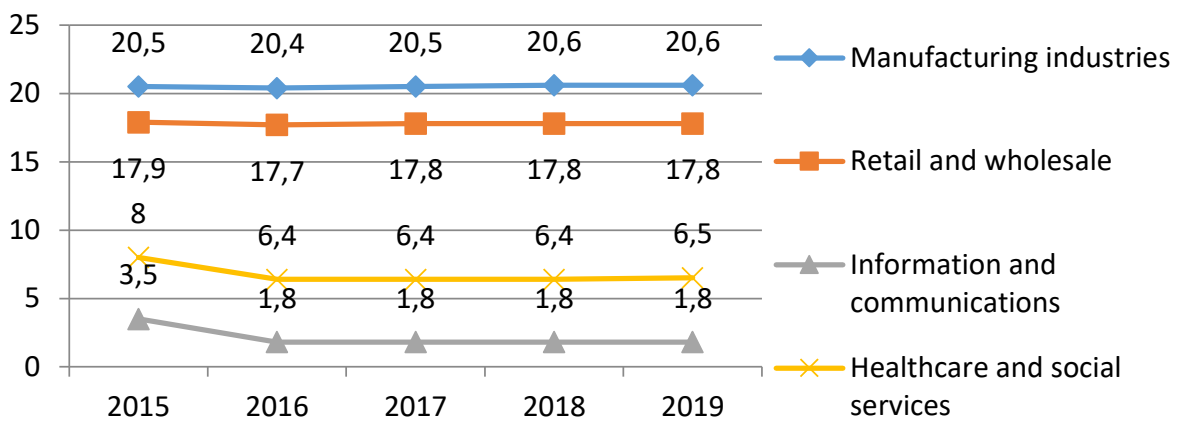

Fig. 1. Dynamics of the structure of the number of people employed in the industrial regions of the Russian Federation by types of economic activity, \%.

Source: [8]

A particularly significant driver of structural modernization at the federal and regional levels of government was the accelerated introduction of digital technologies in response to the numerous restrictions associated with the pandemic. However, as can be seen from Fig. 1 , the share of the number of people employed in information and communications did not undergo significant changes over the period from 2016 to 2019, having decreased by almost 2 times in comparison with 2015. The lack of statistical information on the results of 2020 and the first half of 2021 does not make it possible to identify the undoubted change in this indicator. The basic level of development of Russia's regions, the nature of the structure of their economy, the state of regional budgets - all that has a decisive influence on the ability to do structural maneuver in the above directions.

\section{Globalization and Russian regions in the context of the coronavirus pandemic}

The processes of globalization, while forming the central elements of global economic growth, are at the same time very changeable. Sometimes they affect the whole world, and sometimes the forms of globalization change, and it develops within the framework of free trade zones, various alliances, etc. Moreover, not only the forms are changing but also the pace of globalization. The coronavirus pandemic has had the strongest impact on globalization in terms of restrictions for development. The closure of the borders of numerous countries, the cessation of various businesses broke the value chains and disrupted traditional economic ties. Sanitary and epidemiological requirements have sharply limited the movement of not only people but also goods and services. This situation has provoked the actions of some governments to strengthen the self-sufficiency of their states with a number of critical goods and services. This caused the emergence of new globalization trends in the world, which lead to the formation of alliances of individual countries to solve specific economic problems, that is, the so-called regional globalization is developing [7, p. 26]. The priorities of the economic security of states, rather than market efficiency during the coronavirus pandemic, have become unconditional. However, the economic security of any state, in particular Russia, cannot be ensured in conditions of extreme socio-economic inequality of the regions that form it. Among a number of ways to reduce such inequality in the post-pandemic period, the most desired one may be the deepening of interregional cooperation, the development of cooperative ties that satisfy the interests of both individual Russia's regions and entire macroregions, that is, a kind of "regional globalization" will take place, but country-level. 
An analysis of the vulnerability of the structure of Russia's regions, which increases in crisis conditions, is contained in a number of studies [9, 10,11, 12, 13, 14]. The structural problems of the economy of Russia's regions, which significantly manifested during the coronavirus pandemic, were highlighted by Kuznetsova [15]. Unlike previous crises, the pandemic had a particularly negative impact on the service sector, on economically underdeveloped regions with a low level of development of the real sector and hypertrophied development of the service sector, as well as on those constituent entities of the Russian Federation, which are characterized by specialization in certain branches of the service sector, such as tourism or foreign trade.

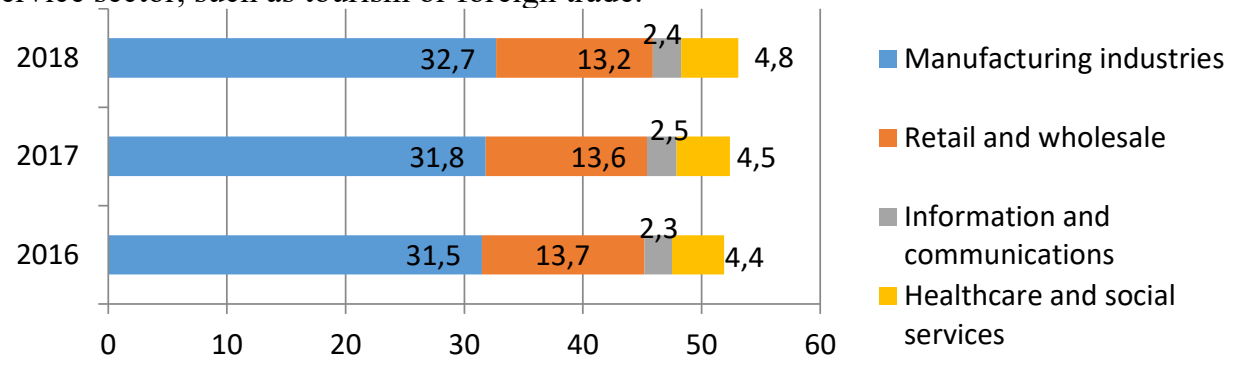

Fig. 2. Change in the structure of GRP in the industrial regions of the Russian Federation by certain types of economic activity, \%.

Source: [8]

For the period from 2016 to 2018, the structure of GRP in industrially developed regions did not undergo significant changes. As a positive aspect of the structural changes, one can note an increase in the share of information and communications, as well as an increase in the share of health and social services.

An important structural problem, aggravated during the pandemic, is the restructuring of both the economy of the regions as a whole, with an emphasis on digitalization, and the restructuring of the service sector.

Table 1. The number of detected cases of coronavirus infection in the regions of the Russian Federation.

\begin{tabular}{|l|c|l|c|}
\hline $\begin{array}{c}\text { Regions with a predominance } \\
\text { of manufacturing in the } \\
\text { structure of the economy }\end{array}$ & $\begin{array}{c}\text { Cases per } \\
\mathbf{1 0 0 , 0 0 0} \\
\text { people }\end{array}$ & $\begin{array}{c}\text { Regions with a predominance of } \\
\text { services in the structure of the } \\
\text { economy }\end{array}$ & $\begin{array}{c}\text { Cases per } \\
\mathbf{1 0 0 , 0 0 0} \\
\text { people }\end{array}$ \\
\hline Novgorod Region & 5553 & Moscow city & 11511 \\
\hline Ulyanovsk Region & 4901 & Saint Petersburg city & 9228 \\
\hline Nizhny Novgorod Region & 4048 & Pskovsk Region & 6504 \\
\hline Kirov Region & 3756 & Moscow Region & 4632 \\
\hline Ulyanovsk Region & 3644 & Voronezh Region & 4094 \\
\hline Tula Region & 3000 & Smolensk Region & 3991 \\
\hline Ryazan Region & 2918 & Ivanovo Region & 3885 \\
\hline Vladimir Region & 2848 & Republic of Crimea & 2759 \\
\hline Perm Territory & 2500 & Primorye Territory & 2608 \\
\hline Sverdlovsk Region & 2279 & Republic of North Ossetia - Alania & 2528 \\
\hline Republic of Mari El & 2202 & Rostov Region & 2442 \\
\hline Chelyabinsk Region & 1946 & Republic of Daghestan & 1244 \\
\hline Republic of Bashkortostan & 1078 & Krasnodar Territory & 975 \\
\hline Average & $\mathbf{3 1 2 9}$ & Average & $\mathbf{4 3 3 8}$ \\
\hline
\end{tabular}

Source: [16] 
As can be seen from the table, the number of COVID-19 cases in regions with a predominance of the service sector in the structure of the economy exceeds by $38 \%$ the same indicator for the regions, with a predominance of manufacturing. The conducted studies indicated the need to restructure the service sector with a significant reduction in the share of such simple services as trade and a growth of comprehensive services that provide not only scientific, technical, innovative activities, but also the development of intellectually capacious areas in the social sphere, primarily in healthcare.

\section{Strengthening the regulatory role of the state}

The latest technological trends, which have increased the uncertainty of the choice of technological priorities, the coronavirus pandemic, which has shown the vulnerability of humanity and the need to rethink the relationship between government and society, demanded a strengthening of the regulatory role of the state [17]. Fukuyama noted in 2020 that in conditions of emergencies on a national scale, no one and nothing could replace a competent state [18]. A high level of technological uncertainty, a difficult geopolitical situation, which have increased the risks of investment activities, primarily of the private sector, make it necessary to maintain investment activity by the state.

The priority areas of such support in various constituent entities of the Russian Federation, defined in the Strategy for Spatial Development of the Russian Federation for the Period up to 2025, as put in numerous studies by domestic scholars, are known, but private investors do not show due interest in their implementation. An increase in the activity of state investments associated with the elimination of the most significant imbalances in the socio-economic development of regions and the introduction of the latest technological solutions there should be a defining signal for businesses, whose investments in fixed assets are significantly lower than gross savings. In modern conditions, the most important areas of public investment are investments in infrastructure, with the everincreasing importance of digital infrastructure, as well as investments in human capital. It is government investments that will initiate private business to follow the same direction, that is, invest in sectors that increase the total factor productivity.

Among the aggravated problems of interterritorial socio-economic differences during the pandemic, it is necessary to note an increasing inequality not only in the level of socioeconomic development of regions, in the degree of their infrastructural provision, in the income from labor and property, but, above all, an increase in a high level of inequality in health care and information and communications. The solution to these problems can only be carried out by the state, whose role in the period of the pandemic and, obviously, even more so in the post-COVID epoch, is radically overestimated throughout the world and is increasingly considered within the framework of the "big state" model. It is the pandemic that has become a powerful factor in the revival of the state throughout the world [19]. Only the state can simultaneously finance priority measures in health care, support the companies whose activities are suspended, employees being on unpaid leave, large families, etc.

Strengthening the role of the state has actualized the importance of the industrial (structural) policy as not only the most important source of innovation and structural transformation of the economy but also such factor as the achievement of monetary stability almost unnoticed earlier [9, 20, 21, 22].

\section{Industrial policy as a tool to reduce interterritorial inequality}

Industrial policy is a well-known tool for the formation of a structurally balanced competitive economy. The current Federal Act "On Industrial Policy in the Russian 
Federation" does not take into account the territorial factor, which hampers its use in order to reduce interterritorial differences in the industrial development of Russia's regions [23]. Currently, a draft "Strategy of the Regional Industrial Policy of the Russian Federation until 2024 and for the Period until 2035" has been prepared [24]. Its implementation is expected in such interrelated areas as increasing coordination of interaction between regions, supporting the development of regional industrial infrastructure and investment activities, strengthening territorial instruments of industrial development. Within the framework of this strategy, special attention is paid to the development of interregional cooperation in order to localize products, strengthen interregional cooperation, and promote the modernization of industrial facilities. The mechanism of special economic zones (SEZ) of industrial production and innovative technology types plays a significant role in leveling the industrial development of Russia's regions. Today, there are 31 SEZ in Russia, 115 territories of advanced socio-economic development have been created, of which 23 are in the Far East and the Arctic, and 92 are in single-industry towns and closed territorial entities.

Expectedly, the attention in the strategy is paid to the formation of an integral system of special economic zones. The research results presented in works $[25,26]$ show that today in Russia SEZ have not become the drivers of socio-economic development of the constituent entities of the Russian Federation. In this regard, an important aspect of the development and implementation of regional industrial policy should be the coordination of priority activities in territories with special economic regimes, including SEZ, with the priorities of regional development. It is necessary to develop greater incentives and guarantees for foreign investors who have finance and new technologies. This may allow them to be more actively involved in SEZ, including those located in underdeveloped regions. Within the framework of regional industrial policy, it is advisable to provide regional authorities with the right to establish profit, property and land tax exemptions for residents.

An important factor in reducing interterritorial differences in the industrial development of Russia's regions is the development of industrial infrastructure with state support. Industrial parks and technoparks are developing quite effectively, the regulatory framework and the system of incentives have been developed in detail. It allows regions to reimburse the costs of creating or modernizing infrastructure, to co-finance the costs of regions on infrastructure building, to establish regional benefits for management companies and residents. In accordance with the data of the Geographic Information System "Industrial Parks. Technoparks. Clusters", by the end of 2020, the regional industrial infrastructure was formed, comprising 311 sites providing residents with more than 35 thousand hectares of land plots, more than 10 million square meters of ready-to-use industrial premises. Almost 6.5 thousand residents are located here, who have created more than 200 thousand jobs.

The success of the strategy of Russia's regional industrial policy will largely be determined by the effective use of such instruments as regional industrial development funds (created in 68 regions of the Russian Federation) and special investment contracts. A feature of the latter, which is important from the point of view of regional interests, is the obligatory participation in contracting of not only the Russian Federation but also of the region of the Russian Federation, as well as its municipalities. A new instrument of regional industrial policy, which is especially important for regions with a low level of socioeconomic and industrial development, is the creation of individual programs for their development. In 2020, such individual programs for 10 underdeveloped regions of the Russian Federation were created and approved by the Government of the Russian Federation.

Programs for such regions should provide for the creation of SEZ in them. As noted above, today such zones are not drivers of regional development. The situation in Russia in this respect is similar to the situation, for example, in Poland. The results of the studies 
carried out there confirm that the activities of firms within SEZ do not allow eliminating the differences in the level of regional economic development [27]. It appears that the strategy of regional industrial policy of the Russian Federation will contribute to turning SEZ into an effective tool to reduce interterritorial inequality in the Russian economy.

\section{Conclusion}

The strategy of Russia's regional industrial policy can be effectively implemented only by taking into account the Strategy of the Spatial Development of the Russian Federation, where the strengthening of interregional cooperation and the coordination of the socioeconomic and industrial development of Russia's regions is assumed within the macroregional framework. This may be one of the factors reducing the differences between regions in terms of their level of resource endowment for industrial growth. To date, in some regions, regional funds for the development of industry have not been created, and in some regions, even the existing regional funds are not adequately provided to support projects in the field of industrial development. Large disparities in the location of industrial infrastructure are also one of the factors of significant differences in the level of industrial development of Russia's regions. In particular, more than $70 \%$ of industrial and manufacturing parks are located in the Central and Volga Federal Districts, while 13\% of such infrastructure facilities are located in regions with a low level of socio-economic development, and in priority geostrategic territories of the Russian Federation.

The implementation of the Strategy for Regional Industrial Policy will allow attracting investments for the development and diversification of the real sector, to create a modern, more rationally localized industrial infrastructure in Russia's regions, to find investment niches, and to increase added value through industrial interregional cooperation of regions. Seeking to reduce interterritorial industrial inequality on the basis of the implementation of the Strategy, it becomes possible to involve the regions in the development of non-standard territorial instruments for stimulating industrial development. This study confirms the need to strengthen the regulatory role of the state not only in the restructuring of the industry but also in the restructuring of the service sector along with the growth of intellectually intensive services in the social sphere, primarily in healthcare.

Acknowledgments: The paper was made in accordance with the research plan for the Institute of Economics of the Ural Branch of the Russian Academy of Sciences.

\section{References}

1. World Economic Forum, COVID Action Platform (Davos, 2020). Accessed on: July 15, 2021. [Online]. Available: https://www.weforum.org/platforms/covid-actionplatform

2. D. Rodrik, In search of prosperity: Analytical narratives on economic growth (Princeton University Press, Princeton, 2003)

3. D. Rodrik, Structural change, fundamentals, and growth: an overview (Institute for Advanced Study, 2013). Accessed on: July 15, 2021. [Online]. Available: https://clck.ru/WDMNT

4. J. Lin, World Bank Research Observer 26(2), 193-221 (2011)

5. World Bank, World development report. Reshaping economic geography (World Bank, Washington, 2009)

6. N.V. Zubarevich, Journal of NEA 2(46), 158-167 (2020) 
7. O.V. Kuznetsova, Moscow University Bulletin. Series 5, Geography 2, 3-8 (2014).

8. Regions of Russia. Main characteristics of the constituent entities of the Russian Federation (2020). Accessed on: July 15, 2021. [Online]. Available: https://rosstat.gov.ru/folder/210/document/13205

9. V.A. Mau, Economic issues 3, 5-30 (2021)

10. N.N. Mikheeva, Spatial Economics 1, 11-32 (2013)

11. N.V. Zubarevich, Regions of Russia: inequality, crisis, modernization (NISP, Moscow, 2010)

12. O.V. Kuznetsova, Scientific Articles: Institute of Economic Forecasting of the Russian Academy of Sciences 2018, 473-493 (2018)

13. S. Zemtsov, V. Barinova, R. Semenova, Forsait 2, 84-96 (2019)

14. O.A. Romanova, Structural modernization of the economy in the context of the fourth industrial revolution, in Strategies for the development of social communities, institutions and territories. Materials of the V International Scientific and Practical Conference. In 2 volumes, 150-155 (Ministry of Science and Higher Education of the Russian Federation, Ural Federal University named after the first President of Russia B. N. Yeltsin, 2019)

15. O.V. Kuznetsova, Federalizm 2, 20-38 (2020)

16. Real-time data. Stopkoronavirus.rf (2021). Accessed on: July 14, 2021. [Online]. Available: стопкоронавирус.pф

17. J. Pisani-Ferry, The challenges of the post-pandemic agenda (Project Syndicate, 2020, July 27). Accessed on: July 15, 2021. [Online]. Available: https://clck.ru/WDMRA

18. F. Fukuyama, Foreign Affairs 99(4), 26-32 (2020)

19. A. Velasco, Are we all Keynesians again? (Project Syndicate, 2020, August 25). Accessed on: July 15, 2021. [Online]. Available: https://clck.ru/WDMRk

20. V.A. Mau, Economic Issues 3, 5-30 (2021)

21. P. Krugman, 2020 was the year Reaganism died (The New York Times, 2020, December 28). Accessed on: July 15, 2021. [Online]. Available: https://www.nytimes.com/2020/12/28/opinion/reagan-economycovid.html

22. X. Vives, A stable Euro requires an ambitious industrial policy (Project Syndicate, 2020, September 4). Accessed on: July 15, 2021. [Online]. Available: https://clck.ru/WDMSM

23. O.A. Romanova, A.O. Ponomareva, Journal of Economic Theory 17(2), 276-291 (2020).

24. TASS, Minpromtorg to develop a strategy of effective industrial policy (2021). Accessed on: July 15, 2021. [Online]. Available: https://tass.ru/ekonomika/10972631

25. A. Vilensky, Federalism 1, 27-43 (2020).

26. G. Galiullia, R-Economy, 5(1), 25-37 (2019).

27. J.M. Nazarczuk, S. Umiński, Foreign Trade in Special Economic Zones in Poland (UWM, Olsztynie, 2019). Accessed on: July 15, 2021. [Online]. Available: https://clck.ru/WDMTN 